\title{
Ethnic Politics, Elite Fracture and Security Dilemma in Ethiopia: New Trends and Scenarios Since 2015
}

\author{
Hadush Redae Kassa, \\ Lecturer,Aksum University, College of Social Sciences and Languages, \\ Department of Civics and Ethical Studies
}

\begin{abstract}
Ethiopia has been battle ground among contesting and competing ethnic identities for centuries and this infamous history of enmity images, perceptions, contradictory narrative, and insecurity dilemma in turn perpetuated mutual fear and mistrust among Ethiopian political elites and opposition leaders, identity groups, national institutions and symbols. This cyclic cause-effect interplay of unpredictable political order has continued to breed sense of insecurity and unresolvable uncertainty manifested in bloody protests, declaration of state of emergency, widespread territorial and identity claims and questions, violation of constitutional provision, disregard of legal protection for citizens, and incapacity to deliver rule, order and security. The post-2015 political unpredictability and uncertainty is washing away the core national and institutional values of democratic governance, equality, rule of law, self-rule and shared rule (ethnic federalism), the prospects for peace, accommodation, and development.
\end{abstract}

Keywords: ethnic federalism, constitutionalism, security dilemma, elite fracture, ethnic protest

DOI: $10.7176 / \mathrm{DCS} / 9-5-01$

Publication date:May $31^{\text {st }} 2019$

\section{Introduction}

Ethiopian governance and decentralization system has been typical part of African tragedy for centuries. Authoritarianism, power contention among strong regional leaders ("Mesafint") based on win-lose relations, absence of rule of law, identity-based conflict and discrimination, recurrent wars and poverty, a center-periphery type of power and resource pattern between the state and society were among the marked characteristics of Ethiopian politics for centuries (Addis Hiwot, 1975; Bahru, 1991; Teshale, 1974; Kinfe, 1994, 2001; Merera, 2002, 2007). The era of modern written constitutions of the country (1931-1991) is also boldly identified with the absence of legitimate leaders, disregard and abuse of ethnic diversity, utter absence of constitutionalism: violation of human and democratic rights, failure to protect and promote interest and sovereignty of the people (Assefa, 2007; Kinfe, 1994, 2001).

Apart from the above, since the last decade of the 20th Century, Ethiopia is known as a prominent case of ethnic federalism (Kidane, 1997). At the end of the war that ousted the ruling military regime in 1991, Ethiopia was divided into autonomous regional states largely based on ethno-linguistic criteria. Two decades later, Ethiopia appears highly decentralized in terms of its framework and how much government activity occurs locally. There are, however, concerns that weak capacity, limited local own-source revenues, and the effects of dominance by a strong political party may limit the extent to which some potential benefits of decentralization can be achieved (LDI LLC, 2013).

Ethnicity and its questions as well as the issue of constitutional order have been a dominant scenario of political development for much of the history of Ethiopia including under the EPRDF rule. Both the Imperial and the Derg regime failed to address the national question, indifference to recognize and embrace ethnicity. As a result, the FDRE constitution adopted ethnic-based federal system to answer the old-held identity driven conflict in the country in the early 1990s (Fasil, 1997; Andreas, 2003).

In multiethnic and multicultural societies, ethnic conflicts are not only recurrent, but often protracted and highly destructive (Newman, 1991). A handful of multi-ethnic and pluralistic countries adopted ethnic-based federalism as a solution to ethnic conflicts in their respective territories. Their experiences show that some of the federal arrangements disintegrated while others survived, and others still struggling to preserve their unity (Muhabie, 2015; Andreas, 2003; Abbink, 1997, 2006).

Ethiopia has more than 80 ethnic groups and over 200 languages and dialects. This diversity has been a source of strength. Yet, ethnic diversity has also led the country to protracted wars among regional leaders and identity groups engineered by contending political elites. The war with Eritrea lasted for 30 years, one of the longest in Africa, and ended with the creation of the state of Eritrea in 1991/1993. The TPLF/EPRDF similarly defeated the military regime in Addis Ababa and planted ethno-linguistic federalism in Ethiopia since 1991(Assefa, 2007, Merera, 2002; Muhabie, 2015; Kebede, 2016).

In fact sponsored by the UN, the history of federalism in Ethiopia dates back to the early 1950s when an arrangement was made between Ethiopia and Eritrea after Eritrea's independence from Italian rule in 1941 and British trusteeship in 1952 in line with UN resolution 390 (v). However, this federal marriage collapsed in 1962 
when Emperor Hailesilassie unilaterally abrogated the federation and annexed Eritrea into Ethiopia as one of the provinces (Negash, 1997; Andreas, 2003). The re-incorporation of Eritrea into the unitary structure resulted in discontent and armed resistance, between the 1960s and 1990s, fought along ethnic lines. Eritrea's armed struggle for independence also set an example for TPLF which fought an armed liberation struggle to initially to separate from, but finally to democratize and restructure, Ethiopia. Consequently, Eritrea declared independence in 1991 (officially confirmed in 1993) while TPLF formed a coalition of ethnic-based liberation fronts, controlled Addis Ababa and established a Transitional Government which adopted a Constitution in 1994/5 that provided for an ethnic-based federal system(Merera, 2002, Kebede, 2016; Muhabie, 2015; Andreas, 2003).

After 1991, Ethiopia embarked on a new chapter of governance and politics in the framework of revolutionary democracy, developmental state, federalism, multiparty system, rule of law and renewed foreign policy and national security strategy viewing threats primarily from within---a human security approach of viewing sources and nature of threats. Today, Ethiopia is not the only country that has created a federal system largely on the basis of ethnicity, language and cultural traits. However, while many of the countries that adopt ethnic federalism tend to systematically avoid provisions for secession and self-determination, the Ethiopian Constitution explicitly recognizes and guarantees these rights. Article 39 of the FDRE Constitution provides that "Every Nation, Nationality and People in Ethiopia has an unconditional right to self-determination, including the right to secession." (FDRE Constitution 1995). Ethnic federalism as a new political system, thinking and space in the post-1991 period promised optimism on peace, democracy and development (Muhabie, 2015; Andreas, 2003).

\section{Methods of the Research}

This research article is based on a descriptive and analytical design of a qualitative approach. The source of data collected for this purpose is primarily secondary sources such as situation assessment and analysis of political changes, trends and dynamics occurring in the Ethiopian political landscape, with due focus on post-2015 leadership and elite fracture-induced ethnic protests, identity and land boundary disputes or claims, constitutional disorder and questions on ethnic-based federal arrangements and symbols such as national flags and institutions. This scholarly article critically absorbs and synthesizes the observations on political camps, reflections, and debates among activists, political figures, opposition parties, the ruling elites, scholars, and the ethnic masses operating peacefully as well as violently in and outside Ethiopia.

\section{Building Blocks of the Ongoing Debates on the Political System}

Several scholars and events are indicating that Ethiopian governance, decentralization, power-sharing (self-rule and shared rule) and ethnic-based federal arrangement is today facing both support and opposition. A closer observation on the country today reveals that there are resurgence tendencies of both centripetal and centrifugal forces, i.e. who celebrate the identity-based federal system and constitution on the one hand and those who extremely reject it.

The central argument of the opponents of the ethnic -based federal system is that in the short-run ethnic federalism may be seen as a solution to problems caused by ethnic tensions and conflicts owing to scarce resources, imbalance of power, exclusion and actual or perceived threats. In the long-run, however, ethnic federalism will tend to amplify differences, increase ethnic cleavages, and persistent demand for greater autonomy by some and the desire to maintain the status quo by others (Muhabie, 2015; Bednar, et al, 1999; Selassie, 2003; McHenry, Jr, 1997 cited in Kebede, 2016).

Others further argue that while the present ethnic-based federal arrangement has resolved some of the old problems of ethnic nationalism and self-rule, empirical evidences also show that it has raised more questions than it has answered. Some of the unresolved issues include problems of delineating ethnic boundaries, recurring violent intra/inter-ethnic and regional conflicts, marginalization of people in some federal states that do not belong to the dominant ethnic group, weak capacity and decision-making power of regional federal states to administer justice; and the combined impact of all these on individual rights which are demonstrated by the continuous narrowing of the political space and the ultimate move toward a dominant one-party "developmental' state (Muhabie, 2015; Merera, 2002, 2007; Kebede, 2016).

Further, a study by Gebre-Egziabher (2007) reported that under EPRDF there have been a number of violent ethnic conflicts widespread throughout the country. Among the major causes identified by the author include: Ethno-Centric Federalism and Ethno-Centric Politics: ethnic based regional boundaries and non-clarity resulted in the separation of ethnic groups from their traditional resource bases; using ethnicity for political mobilization (Politicisation of Ethnicity): ethnicity becomes the most efficient base for political mobilization, and it gives enough ground for new local elites to compete for power on the basis of ethnicity; dissatisfactions that exist in the country as a result of absence of public accountability and non-observance of the rule of law by government officials result in grievances that eventually lead to conflict situations (see also Muhabie, 2015; Merera, 2002, 2007; Kebede, 2016). 
Another study by Adegehe (2009) concluded that: Ethnic federalism prevents the development of a countrywide overarching citizenship; restructuring multiethnic states into ethnic federations tends to generate intrafederal (violent) conflicts; a constitutional guarantee for secession prevents the development of the appetite for compromise and encourages separatist nationalism.

Other critiques on ethnic federalism also come from those which see a causal relationship between promoting group rights at the expense of individual rights. Though the two do not conflict, these camps say, group rights are too general, too diffuse and hard to substantiate. It is often argued that the assertion of one group's right could lead to the suppression of the rights of others, especially those considered "beneficiaries" of previous systems. In the case of Ethiopia, critics of the present system argue that ethnic federalism was introduced to divide and rule, to weaken opposition from the previously dominant groups, and most importantly stifle liberal democracy which gives primacy to individual rights before or parallel to group rights (Muhabie, 2015; Kebede, 2016).

\section{Looming Cases of Security Dilemma in Ethiopian Politics}

The recently appearing national and local level inter-ethnic and governance unpleasant dynamics particularly since 2015 has posed new questions on constitutional order and unity in diversity challenges: including (1) the Wolkayt-Tsegedie "identity-boundary" issue, (2) the Gichew "border land" contention and claim between Tigray and Amhara regional states, (3) the Amhara-Oromo protests, particularly the violent ethnic targeting events in Gonder and Metema which have led to national state of emergency, (4) the referendum of "Qimant" identity groups in Amhara region and related crisis, (5) the recent violent conflict between Somali and Oromo who killed and displaced in masses, (6) the administrative questions or claims of woreda-wise Embaseneiti in Tigray region, (7) the violent inter-ethnic conflict in Southern nations, nationalities and peoples region, (8) the ongoing bloody crisis in Somali regional state, and military intervention (9) the "Raya identity question" claimed by groups in Addis Ababa.

Thus, there is today widespread concern on violation of constitutional order and the respect, protection and promotion of fundamental constructional rights, freedom and principles as evidenced by the events mentioned above. There are some supporting cases to such questions on constitutional orders (rights and freedoms), ethnolinguistic based federal governance and self-rule: Ethiopian Human rights commission report (2018) on crimes committed against prisoners; EPRDF-led government leadership crisis/elite fracture-induced competition, instability and fear; EPRDF renaissance/deep renewal appraisal report on mal-governance and violation of rule of law; violation of the right to movement, security of the person and property under FDRE constitution; disregard of the right to compensation and support during displacement; failure of the governing regime's duty to respect and protect citizens and the constitution and federal system, like the Ethiopian flag issue; failure to enforce the constitutional provision to separate powers of the party from the government (see FDRE Constitution 1995 for the rights, freedoms, principles and provisions).

Thus, the constitutional order and ethnic-federal arrangement in post-1991 Ethiopia is coming into a new chapter now along with multiple and complex questions of power, wealth/resource distribution, identity and legal matters with much implications to be occurred. So the Ethiopian prospect for peace and democracy in the framework of ethnic federalism and rule of law has recently been challenged since 2015 and it needs fresh investigation and perspective.

Recently, EPRDF's Ethiopia has experienced two phases of leadership change with important meaning and implication to the nature and trend of its constitutional order and federal system. One is the August 2012 transition which brought PM Hailemariam Desalegn to power and the other the February 2018 transition which brought PM Abiy Ahmed to power. The August 2012 transition is a case of the leadership change with regime stability scenario. Scholars, commentaries, analysts who closely follow and study political developments in Ethiopia also have no/little ambiguity and controversy about this. By contrast, the February 2018 transition has been and is still generating a lot of doubts, ambiguities, debates and controversies about its nature and trend of dynamics. To many, it is arguably a case of the leadership change with instability scenario. Here, opinions and perspectives are sharply divided as some view the transition as transition by and towards democracy while others view it as a transition by and towards autocracy/and perhaps to disintegration.

Despite scholars', analysts', activists', commentaries', politicians' and policy makers' ongoing efforts to analyze, and systematically capture the problem occurring in the recent political development of Ethiopia as well as its implication to and effects on national security, constitutionalism and ethnic federalism, a comprehensive and detailed analysis of the real nature and the end state of the new changes and challenges has not yet been established and it requires additional further and holistic research.

\section{Conclusion and the way forward}

The issue of governance, decentralization and democratization are broadly and often differently understood as definitions and experiences indicate. Such a system of ruling society or state are worth understanding and also 
studying such topical themes are particularly relevant to Africa and Ethiopia because both cases of study are suffering from lacks and shortages of this attributes in general terms. Africa has been typical example of democratic deficit because of domestic and external problems ranging from personal and authoritarian rule, weak institutions, poverty, and underdevelopment, weak or no media and civil society, poor legal and electoral processes, colonialism and its legacy, and so forth. Ethiopian Experience of governance and decentralization has been similar to African general huge problems until the end of the cold war period but significantly changed after the coming of the EPRDF to power and the radical restructuring of the Ethiopian governance and political system since 1991. In fact, recently, Ethiopian prospect for peace, democracy and development in the framework of ethnic federalism and rule of law has been challenged and it is with mixed realities of changes and continuities on accounts of national security, constitutional order, regime stability, and decentralization. And it is plausible to conclude that leadership and elite fracture in the context of ethnic politicization and shifts in power players and their alliances has placed Ethiopia at crossroads nowadays. Its future also carries threats of national security and survival, and also huge potentials of reversal. Peace-building, inclusive nation-building, consolidation of democracy via institution-building and entrenching rule of law to hold leadership and government transparent and accountable is recommended as ways forward.

\section{References}

Abbink, J. (1997): "Ethnicity and constitutionalism in contemporary Ethiopia", Journal of African Law, 4th Quarter.

(2006). Ethnicity and Conflict Generation in Ethiopia: Some Problems and Prospects of EthnoRegional Federalism, Journal of Contemporary African Studies24 (3).

Addis Hiwot (1975) 'Ethiopia: From Autocracy to Revolution, Occasional Publication No.1 of Review of African Political Economy, London.

Andreas Eshete (2003). Ethnic Federalism: New Frontiers in Ethiopian Politics, First National Conference on Federalism, Conflict and Peace Building, Addis Ababa: Ministry of Federal Affairs and GTZ.

Assefa Fiseha (2007): Federalism and the Accommodation of Diversity in Ethiopia. A Comparative Study. Nijmegen: Wolf Legal Publishers.

Bahru Zewde (1991) A History of Modern Ethiopia, 1855-1974. London: James Currey.

Bednar, J., William N. E. Jr., John F., (1999). A Political Theory of Federalism.

Fasil Nahum (1997). A Constitution for a Nation of Nations: The Ethiopian Prospect (Red Sea Press, Lawrenceville, $\mathrm{NJ}$ )

Federal Democratic Republic of Ethiopia (FDRE) (1995) 'The Constitution of the Federal Democratic Republic Of Ethiopia', Federal Negarit Gazeta 1st Year No. 1, 21st August 1995 (Addis Ababa).

GebreEgziabher, S. (2007). "What Role Should Civil Society Organisations Play To Address Ethnic Conflicts In Ethiopia Paper To Be Presented At The Fourth International Conference on Ethiopian Development Studies (4th ICEDS) on The Challenges And Opportunities For Peace \& Development In Ethiopia \& Northeast Africa.

Kebede Kassa (2016). The Long-Term Consequences of Managing and Settling Ethnic Conflicts through Ethnic Federalism: The Case of Ethiopia. ISSN: 2320-5407, Int. J. Adv. Res. 4(9), 23-29

Kidane Mengisteab (1997): "New Approaches to State Building in Afirca: The case of Ethiopia's ethnic based federalism." African Studies Review 40, pp.111-132.

Kinfe Abraham (2001). Ethiopia: From Empire to Federation, NINA Press, Uppsala. ISBN 9789163119828

(1994). Ethiopia: From Bullets to the Ballot Box, Red Sea Press, AWP New Jersey, US. ISBN 0932415792.

Local Development International LLC (2013). "The Role of Decentralisation/Devolution in Improving Development Outcomes at the Local Level: Review of the Literature and Selected Cases Prepared for: UK Department for International Development South Asia Research Hub" Brooklyn, New York. USA, November 2013

McHenry, D. E., Jr. (1997). "Federalism in Africa: Is it a Solution to, or a Cause of, Ethnic Problems?" Presented at the Annual Meeting of the African Studies Association in Columbus, Ohio, (November 1997).

Merera Gudina (2002) Ethiopia: Competing Ethnic Nationalisms and the Quest for Democracy, 1960 -2000. The Hague, the Netherlands: Shaker Publishing.

(2007). Ethnicity, Democratization and Decentralization in Ethiopia: The Case of Oromia, Eastern African Social Sciences Review 23(1).

Muhabie Mekonnen (2015). Ethnic Federalism: A Means for Managing or a Triggering Factor for Ethnic Conflicts in Ethiopia, Social Sciences. Vol. 4, No. 4, 2015, pp. 94-105. doi: 10.11648/j.ss.20150404.15

Selassie, Alemante G., "Ethnic Federalism: Its Promise and Pitfalls for Africa" (2003). Faculty Publications. Paper 88. ttp://scholarship.law.wm.edu/facpubs/88

Singh, Y. (2006) Fundamentals of Research Methodology and Statistics: New Age International, New Delhi 
Tekeste, N., (1997). “Eritrea and Ethiopia: The Federal Experience. New Brunswick, NJ: Transaction Publishers, http://findarticles.com

Teshale Tibebu (1995). The Making of Modern Ethiopia, 1896-1974. Lawrenceville, NJ: The Red Sea Press. 